Article

\title{
Sustainable Education, Emotional Intelligence and Mother-Child Reading Competencies within Multiple Mediation Models
}

\author{
Elena Jiménez-Pérez ${ }^{1}$, María-Isabel de Vicente-Yagüe Jara ${ }^{2, *(D)}$, Raúl Gutiérrez-Fresneda ${ }^{3}$ (D) \\ and Pedro García-Guirao 4 (D)
}

1 Department of Didactics of Language and Literature, Faculty of Education Science, Campus de Teatinos, Universidad de Málaga, 29071 Malaga, Spain; elenapjimenez@uma.es

2 Department of Didactics of Language and Literature, Faculty of Education Science, Campus Espinardo, Universidad de Murcia, 30100 Murcia, Spain

3 Department of Development Psychology and Teaching, Universidad de Alicante, Carretera de San Vicente del Raspeig s/n, 03690 San Vicente del Raspeig, Spain; raul.gutierrez@ua.es

4 Romance Studies Department, Faculty of Arts, University of Ostrava, Mlýnská 5, 70200 Ostrava, Czech Republic; pedro.garcia@osu.cz

* Correspondence: isabelvyague@um.es

\section{check for} updates

Citation: Jiménez-Pérez, E.; de Vicente-Yagüe Jara, M.-I.; Gutiérrez-Fresneda, R.; García-Guirao, P. Sustainable Education, Emotional Intelligence and Mother-Child Reading Competencies within Multiple Mediation Models. Sustainability 2021, 13, 1803. https://doi.org/ $10.3390 /$ su13041803

Academic Editor: Eloy López Meneses

Received: 23 January 2021

Accepted: 3 February 2021

Published: 7 February 2021

Publisher's Note: MDPI stays neutral with regard to jurisdictional claims in published maps and institutional affiliations.

Copyright: (c) 2021 by the authors. Licensee MDPI, Basel, Switzerland. This article is an open access article distributed under the terms and conditions of the Creative Commons Attribution (CC BY) license (https:/ / creativecommons.org/licenses/by/ $4.0 /)$.

\begin{abstract}
The influence of the family on the education of children is indisputable, and the mother plays a fundamental role as a direct influence on the educational process of children, especially on their reading competence. Systematically, the role of education has been delegated to the teacher when, even in academic aspects, the values of a society influence the education of the new generations. A sustainable society goes through a sustainable education, instilling values from a well-developed emotional intelligence. The objective of this study is to establish for first time the existence of relationships among reading habits, sex, and mother's emotional intelligence regarding the reading comprehension of children. Participants included 521 adolescent baccalaureates aged between 16 and 17 years old, who attended three public baccalaureate schools in the province of Málaga and four public high schools in the province of Granada, all located in areas of medium socio-cultural context. Mediation and factorial analysis of covariance (ANCOVA) analyses were performed. The results show that girls with higher emotional intelligence and whose mothers have higher reading habits obtain higher reading competence.
\end{abstract}

Keywords: reading competence; emotional intelligence; baccalaureate; mediation analysis; factorial ANCOVA

\section{Introduction}

We have the assumption that learning for life is traced within families, education begins within the family and the sustainability of society is rooted in that education. It is transmitted from grandparents to parents, and from parents to grandchildren. It also seems that cultural and social learning is established in this way. From this point of departure, it is interesting to analyze how the reading habits and, by extension, the acquisition of reading competences begins and develops in the family environment, because the family is the first socializing and cultural element of the learner.

In this direction, objective four of the UNESCO [1] Sustainable Development Agendaa collection of 17 interlinked global goals to fulfill a "better and more sustainable future for all"-already pointed, as an innovative strategy, that the family environment is one of the fields where the transformative change of learning operates. It is in the bosom of the family where the most important educational germ is produced, education in values that, as the first learning, generally comes from the hand of a consolidated reading habit. 
This learning is linked to the development of reading competence, which is closely related to school performance, according to reports such as the so-called Program for International Student Assessment or PISA [2], citizens committed to culture and art (reading, writing, visiting museums...) rather than the culture of consuming or watching TV. It is already included in the Spanish Royal Decree 1105/2014 of 26 December, which establishes the basic curriculum of secondary and compulsory education and of the baccalaureate, that one of the fundamental objectives that must be developed in the baccalaureate is "to secure habits of reading, study and discipline, as necessary conditions for the effective use of learning, and as a means of personal development" [3] (p. 188). In this sense, the development of reading habits and the associated reading comprehension are a concern that is being addressed in current studies through various procedures [4], since they are a necessary base for the process of student socialization $[5,6]$.

\subsection{Family, Learning, and Reading}

Family as an engine for sustainable change, for the extension of the reading culture, should be the main reading space. Several international studies reveal the importance of the family environment, in addition to other reading spaces such as schools and libraries, in academic performance-always related to motivation-and, especially, in the process of acquiring reading habits [7-10]. This situation leads us to consider in this study the approach of the family environment as a variable of study in the development of reading habits, as well as reading comprehensively [11-13]. Gómez-Quina [14] (p. 59) also points to the following idea: "If the family does not provide an environment rich in both writing and reading experiences, it is very difficult for the child to hypothesize and build knowledge about reading and writing". Other studies have shown that the level of study and the cultural origins of parents are often influential factors in the acquisition of constant study and reading habits for students $[15,16]$.

In primary school, basic activities can be practiced as a family, the bedtime story is well known but little practiced during the first years of childhood [17], as well as activities related to reading aloud by adults.

As indicated by Pascual [16] (p. 315): "Si tenemos en cuenta la influencia familiar en la creación y consolidación de los hábitos lectores de sus hijos, la acción educativa deberá transcender más allá de lo meramente escolar y abordar actuaciones que fomenten la animación lectora a la familia y a la sociedad en la que ésta se incardina" (If we consider the family influence in the creation and consolidation of the reading habits of their children, the educational action must transcend the school and address actions that encourage reading in the family and society).

Taking into account the aforementioned comments, one could say that both the family and the school are the first sources of children's contact with reading and the habits around it, but as Márquez [18] (pp. 11-12) indicates, "The reading habits can originate at home, but the role of the school is key in the contexts of poverty and the community, they provide little help to acquire that learning". Jiménez-Pérez [19] already said that the habit of reading should be considered as reading inertia, although it is not reflected directly in the laws of education in Spain. Braslavsky [20] maintains that we can assume that minimum levels of acquisition of reading and writing processes should be established through collaboration among families, the family environment of the child, and the school. On the other hand, the family structure can be considered as a variable contemplated to observe the most specific sociological characteristics of the family context, such as whether the student lives with his father or mother, or both [21]. It should be noted that comparative studies between countries indicate that there is a gap in school achievement between students who live in families with both parents and those who live in single-parent families or with the father or mother absence [22].

On the other hand, studies highlight the fact that the results of the development of cognitive, emotional, or intellectual capacities depend, to a large extent, on the social rooting or uprooting of the family or on the support provided by official institutions [23-26]. 
Regarding the support from the official institutions of each country, it can be affirmed that, although many of these educational systems dedicate part of their curricular organization to fulfil the objectives of reading, reading habits, or reading comprehension, the results are not always what is expected or what is desirable [27]. Therefore, it is not only about the low reading levels of primary or secondary students; the problem also involves the low reading levels of the adult population [28].

In line with the results of the study by Miller, Topping, and Thurston [29], MoraFigueroa, Galán, and López-Jurado [30] demonstrated, from a family reading program, that students with reading difficulties in primary education improved their reading performance when the family environment was involved in the process of acquiring reading habits. Likewise, other studies have shown that the perception-positive or negative-that the student shows towards the reading habit depends, to a large extent, on how the parents present reading activities to their children in the family environment. The value that mothers and fathers give to reading, their reading habits, and the quality of reading material is related to their children's attitudes towards reading [31]. When students learn that reading is a tool that helps them to decode written symbols inserted in messages of daily life, they begin to place greater importance on reading as a study habit [32].

Going a step further in education, analyses have been developed with subjects in university education that have traced the reading habit that students acquire during their academic development. According to the results, university students prefer to read in their own home, rather than at the university $[33,34]$. In addition, we cannot ignore that these students, like those of primary and infant education, form their reading habit using information and communication technologies (ICTs). Both the reading process and the acquired habit will also be conditioned by the usability of ICTs (another worthy variable of study) and the current ways of reading all types of text [8], since the textual typology has varied with current technologies [19,35-37].

\subsection{Reading and Maternal Influence}

From another point of view, studies applying the Wechsler Intelligence Test shed light on the influence of maternal education in the process of the development of cognitive abilities [38]. The results indicate a relationship among the educational level, age, and socioeconomic characteristics of the mother that directly influence the intellectual development of infants. It is revealed that, with a higher educational level of the mother, even with levels of studies "slightly higher" than those of the father [16] (p. 343), the boy or girl will be favored to achieve better academic performance.

In this line, the PIRLS-TIMSS 2011 report (international study of progress in reading comprehension, mathematics, and science) revealed, in the case of performance in reading, that the children of mothers with higher educational levels than the father show more advantageous scores than those of the children of mothers with educational levels lower than those of the father [39] (p. 166). This situation may be motivated by the greater role that mothers continue to play in the upbringing of children, being one of the family members who spend the most time helping with homework at home [40,41]; as a consequence, a higher qualification of mothers, produces roughly better academic outcomes.

According to González et al. [7], children choose different places of reading such as school or, in many cases, the family home, as a second option, even the workplace of the mothers. The idea that there is a latent problem has already appeared, but little studied, which reveals that mothers are an essential element in the development of their children's learning, question on which we want to deepen this work. On the other hand: "La creciente participación laboral de las mujeres que buscan contar con ingresos monetarios para el bienestar familiar está ligada a la dinámica del mercado laboral, que presentan jornadas sobrecargadas que originan el poco interés o escasa motivación para participar en la vida de la escuela" (The increasing labor participation of women who seek to have monetary income for family well-being is linked to the dynamics of the labor market, which present 
overloaded days that cause little interest or little motivation to participate in the life of the school.) [42] (p. 167).

In this sense, Larrañaga and Yubero [43] stated that children perceived that adults in their environment liked to read, but that it was the mother who devoted most of their time to it, after teachers, emphasizing the maternal reading habits that are the focus of the present study. In many cases, the figure of the mother is fundamental in transmitting from values to habits, so it can be one of the most important gears in the sustainable transformation of society to objectives of social improvement.

\subsection{Emotions and Reading}

From a different perspective, it is possible to introduce another element of study in the present work if we take into account that reading and emotional intelligence are two interrelated elements that affect the student's school environment [23,44-47]. Certain studies have specified that not only are teacher-student relationships more positive, but work habits improve considerably $[7,48,49]$. The ability of students to express their own emotions through speech or writing has been associated with sustained academic and social achievement: participants demonstrated significant improvement in social and emotional skills, behavior, and academic performance [50].

Several studies have found that secondary students with a high motivation for reading improve their results in mathematics, vocabulary, and oral expression $[15,51,52]$ compared to those who read only from time to time. That is, the academic performance establishes a relation with the habit and the training of reading comprehension, which affect the variables of the operative memory of the student [53].

Mayer and Salovey [54] (p. 20) already argued with respect to the binomial of the studied emotional intelligence that "literature is probably the first home of the emotional intelligences". In this sense, authors consider reading an essential instrument for the development of emotional competencies [49,55-57] and they are the cornerstone of the evolution of society from a sustainable perspective. Considering this approach, it seems possible to understand reading as a significant tool that allows the identification and empathy of the reader with their characters, while encouraging students to externalize their emotions, doubts, and fears. These emotions evoked during the reading were pointed out in the study by Johnson [58], explaining how certain readers who had just read a story that encouraged sympathy or compassion described feeling more empathic emotions and were more likely to exhibit behaviors of help.

If we also add to the binomial that titles this section (emotions and reading) the maternal figure, we should highlight the study by Aram and Aviram [59], which shows that the selections of books made by mothers are related to the socio-emotional development of their children. According to the results, the mothers whose questionnaire about reading in relation to the emotions raised was answered in a similar way to the experts in children's literature, had children evaluated by their teachers with greater emotional harmony, and balanced people reinforce a sustainable society. In addition, other studies reveal that the usual reading of children ages four to six by their families allowed them to identify desires and beliefs different from their own, as assessed by the tasks of the theory of mind, specifically the proven success in the tasks of false beliefs. It is explained in this sense that the use that mothers make of the language of mental state during reading can help their children develop an understanding of the psychological world, because the frequency and the varied use of cognitive and emotional terms correlated positively with the performance of the false beliefs of children $[60,61]$.

As we have seen, there are many studies on emotional intelligence and education, or on reading competence and education, or on family and education, but none relates to how a maternal social habit can influence the formal education of their children, depending on emotional intelligence. This is the first study that seeks to give scientific argumentation to what intuition and logic already point out. 
Therefore, this study has a general objective to evaluate the influence of the variables of maternal reading habits, sex, and emotional intelligence on reading comprehension in high school students. The specific objectives are to:

(1) Examine whether the relationship between sex and reading comprehension (RC) is mediated by emotional intelligence (EI).

(2) Examine whether the relationship between sex and RC depends on the moderating effect of maternal reading habits (MRH).

(3) Examine whether the relationship between sex and RC is mediated by EI and, in turn, whether this relationship changes according to the values of MRH.

(4) Examine differences in RC based on MRH, controlled sex, and the effect of EI.

\section{Materials and Methods}

The present study was established with a longitudinal quasi-experimental design for a sample of high school students framed within the Spanish academic curriculum located in the autonomous community of Andalusia, for the first course of the educational stage. The ethical indications necessary for an investigation on human beings have been respected, and the following guidelines were taken into account: informed by the right to information and protection of personal data; confidentiality guarantees; guarantees of non-discrimination for any reason; and free intervention that can be abandoned at any time at the request of the student.

\subsection{Participants}

The sample consisted of 521 adolescents in the first year of high school (46.8\% male, $53.2 \%$ female), aged between 16 and 17 years $(M=15.98, S D=0.14)$. Three public secondary education centers from the province of Málaga $(\mathrm{N}=264)$ and four public secondary education centers from the province of Granada $(\mathrm{N}=274)$ participated. The centers were located in areas of medium socio-cultural context. The sample selected was for research convenience.

\subsection{Measures}

- $\quad$ Reading competence test (CompLEC) [62]: The test is composed of five texts, of which three are continuous and two discontinuous, with a total of 20 questions prepared following the PISA 2000 parameters. The length of the texts varies from 274 to 426 words, and the texts are mainly expository and argumentative, in relation to the continuous and diagram and graph with a minimum of 130 words the discontinuous texts. The questions are open-ended and closed-ended types but predominantly multiple choice, because this test has been designed with the aim of programming it to facilitate its correction. For this reason, open-ended questions would hinder this purpose, because they cannot completely enclose certain types of questions from a computational linguistic point of view. The 20 questions are divided, following PISA guidelines, into information retrieval, integration, reflection on the content, and form of the text. The CompLEC obtains satisfactory internal consistency $(\alpha=0.79)$ and corrected homogeneity indexes of the items with values between 0.41 and 0.48 . Although this test has been designed for adolescents of 15 years, the texts and questions that have been used are perfectly valid for higher age ranges, since the types of texts and questions suggested by the PISA have been used for both schoolchildren and adults.

- Spanish version [63] of the Wong and Law Emotional Intelligence Scale (WLEIS) [64]: This scale is made up of 16 items with a seven-point Likert-type scale response format that evaluates emotional intelligence in the organizational area, structured in four dimensions: (1) evaluation of one's own emotions; (2) evaluation of the emotions of others; (3) use of emotions; and (4) regulation of emotions. It allows obtaining a total score, so that the higher the score, the greater the emotional intelligence. The test is administered to subjects from 16 years of age, so it is appropriate for the present study. It shows satisfactory internal consistency values measured by the Cronbach alpha 
coefficient $(\alpha)$, oscillating between 0.83 and 0.90 . In the study sample, the results are like those of the original version, obtaining values of internal consistency for the four dimensions between 84 and 0.89 , as well as an $\alpha=0.89$ for the total score.

- $\quad$ Basic reading habits questionnaire: The questionnaire was published by the Spanish Ministry of Education, Culture and Sports [65] and consists of 50 questions addressed to high school students. The test aims to obtain information about the socio-economic situation of students, as well as their reading habits and the reading context that surrounds them. The items directly related to reading habits were selected, discarding those of a socio-economic nature, that is, from question 6 to question 20: the reader is considered, the father reads, the mother reads, books are given, questions are asked about reading, reading is recommended, there are books at home, there is talk of books, teachers recommend, use of the library, attendance at the book fair (added), awareness of the taste for reading, teachers encourage reading, parents encourage reading, and desire to read.

\subsection{Procedure}

A session of two hours prior to any action was carried out to give instructions to the teachers of the centers responsible for carrying out the tests and answer possible doubts. We sought to establish the best way to pass the questionnaire so that the students were not tired, stressed or unmotivated and thus ensure a more objective performance of the students. Therefore, we agreed that the teachers of the subject administered the questionnaires during the last week of the academic year on three alternate days (one questionnaire per day), in the usual classrooms, to prevent fatigue among those students. The exams had ended a week before, to avoid stress. The first questionnaire that was used was that of Reading Habits of the Spanish Ministry, on a Monday at the third hour of class. The second was the emotional intelligence one on Wednesday at the same time, 10:30 a.m. The last one was held on Friday in the same time slot. The time is the one that seemed most appropriate to avoid fatigue (last hour) or lack of interest (first hour). The reading habits questionnaire lasted $50 \mathrm{~min}$, the emotional intelligence $15 \mathrm{~min}$ and the reading skills $50 \mathrm{~min}$. No student needed extra time and there were no incidents in the development of the tests in the usual classrooms.

The questionnaires were scored by the authors of the present study.

\subsection{Analysis of Data}

In the first place, descriptive analyses of the variables of $\mathrm{RC}, \mathrm{EI}$ according to sex, and MRH were carried out. Subsequently, linear regression analysis was performed using models of mediation, moderation, and moderate mediation. In this context, we used the concepts of mediating variable (M), which assumes an indirect effect, and moderating variable $(\mathrm{W})$, which supposes a conditional effect, in addition to the widely known independent or predictor variable $(\mathrm{X})$, dependent variable or result $(\mathrm{Y})$, and covariate.

First, a mediation analysis was carried out to explain how or why an independent variable produces a certain effect on a dependent variable (i.e., explain the causal relationships). The mediating variables can be variables of different kinds (cognitive, affective, biological, behavioral, etc.) that are related to the independent variable and the dependent variable. As indicated above, the mediating variables suppose an indirect effect, which quantifies the effect of the independent variable on the dependent variable through the mediating variable. This analysis allows to obtain theoretical explanations that help to understand the underlying processes that occur in reality.

Secondly, a moderation analysis was carried out to analyze the circumstances under which the effect occurs (i.e., when or in what situations this effect occurs). This analysis examines whether the relationship between the independent and dependent variables changes in the different levels of the moderating variable, so that the sign and strength of the relationship between both variables depend on the influence of the moderating variable. The moderator is included in the analysis as an interaction term [66]. 
Third, a moderate mediation analysis was carried out, which combined the analysis of mediation with the analysis of moderation, making it possible to discover whether the mediating variable produces a differential effect in the different categories of the moderating variable. Therefore, suppose that the mechanisms that explain the effects of an independent variable on a dependent variable can be different depending on certain moderating variables.

In the mediation, moderation, and moderate mediation analyses, the variables under study were the following: the total score in $\mathrm{RC}$ is the dependent variable $(\mathrm{Y})$, the sex the independent variable $(\mathrm{X})$, the EI score the mediating variable $(\mathrm{M})$, and the $\mathrm{MRH}$ the moderating variable $(\mathrm{W})$. In the analysis of mediation, three types of effects are calculated: the total effect (c) quantifies the effect of sex on $\mathrm{RC}$; the indirect effect $(\mathrm{a} \times \mathrm{b})$ quantifies the effect of sex on RC through EI; and the direct effect $\left(c^{\prime}\right)$ measures the effect of sex on $R C$, eliminating the indirect effect of the total effect of sex on $R C\left(c^{\prime}=c-a \times b\right)$. There is mediation when the direct effect $\left(c^{\prime}\right)$ decreases when adding the mediation effect $(a \times b)$. To test the statistical significance of the indirect effects, the bootstrapping method with 5000 bootstrap samples was used to construct the $95 \%$ confidence intervals, since it is considered the best in terms of power and type I error.

In the analysis of moderation, the variable of $\mathrm{MRH}$ is introduced as a moderating variable. This analysis examines whether the relationship between sex and RC changes at different levels of MRH. Then, a moderate mediation analysis was carried out to check whether the relationship between sex and RC is mediated by EI and, in turn, whether this relationship changes according to the values of MRH. For this, the moderate mediation index $\left(b_{3}{ }^{m} \times b_{2}{ }^{y}\right)$ was calculated, quantifying the indirect conditional effect of the sex variable on RC. This effect indicates how the effect of sex on RC through EI changes according to the values of the MRH. To test its statistical significance, the bootstrapping method with 5000 bootstrap samples was used to construct the $95 \%$ confidence intervals.

Finally, for verifying that EI mediates the relationship between sex and EI, a $2 \times 2$ factorial ANCOVA was performed. The dependent variable was the total score in RC, and the factors were the MRH (yes or do not), sex (woman or man), and the covariable score in EI. The objective of this analysis was to control the effect of the covariate (EI score) on the relationship between the variables of sex and MRH with RC scores. In this analysis, the magnitude indices of the association $\left(\omega^{2}\right.$ partial $)$ and effect size $f$ (Cohen, 1988) were calculated.

\section{Results}

\subsection{Descriptive Analyses}

The results of the descriptive analysis of the variables of RC and EI according to the sex and the MRH are shown in Table 1.

Table 1. Average descriptive statistics $(M)$ and standard deviation $(S D)$ of the variables reading comprehension $(R C)$ and emotional intelligence $(E I)$ according to sex and the mother's reading habits (MRH).

\begin{tabular}{cccccc}
\hline \multirow{2}{*}{} & & \multicolumn{2}{c}{$\boldsymbol{R C}$} & \multicolumn{2}{c}{$\boldsymbol{E I}$} \\
\cline { 3 - 6 } & & $\boldsymbol{M}$ & $\boldsymbol{S D}$ & $\boldsymbol{M}$ & $\boldsymbol{S D}$ \\
\hline \multirow{3}{*}{ Sex } & Woman & 14.38 & 3.13 & 80.63 & 18.23 \\
& Man & 13.31 & 3.01 & 90.78 & 16.36 \\
& Yes & 14.23 & 3.14 & 88.60 & 19.12 \\
& Do not & 13.38 & 3.02 & 82.39 & 15.55 \\
\hline
\end{tabular}

The results obtained indicate that adolescent girls show a higher average in reading comprehension and emotional intelligence than adolescent boys. Likewise, adolescents with mothers with reading habits again show higher average scores in reading comprehension and emotional intelligence. 


\subsection{Mediation Analyses}

In order to analyze if the relationship between sex and RC is mediated by EI (objective 1), a mediation analysis was carried out. The results show that the effect of the sex variable on EI is statistically significant (a), which indicates the existence of a relationship between both variables in the sense that girls to obtain better EI scores higher than boys, as well as the effect of EI on RC controlling for the effect of sex (b), This again shows the relationship between these two variables, and shows that the higher the score in EI, the higher the CR scores tend to be, maintaining control over the variable sex. In turn, the direct effect of sex on RC was also significant ( $c^{\prime}$ ) (Figure 1), which shows the relationship between these two variables showing that girls show higher CR scores than boys, without taking into account the effect of the variable IE.

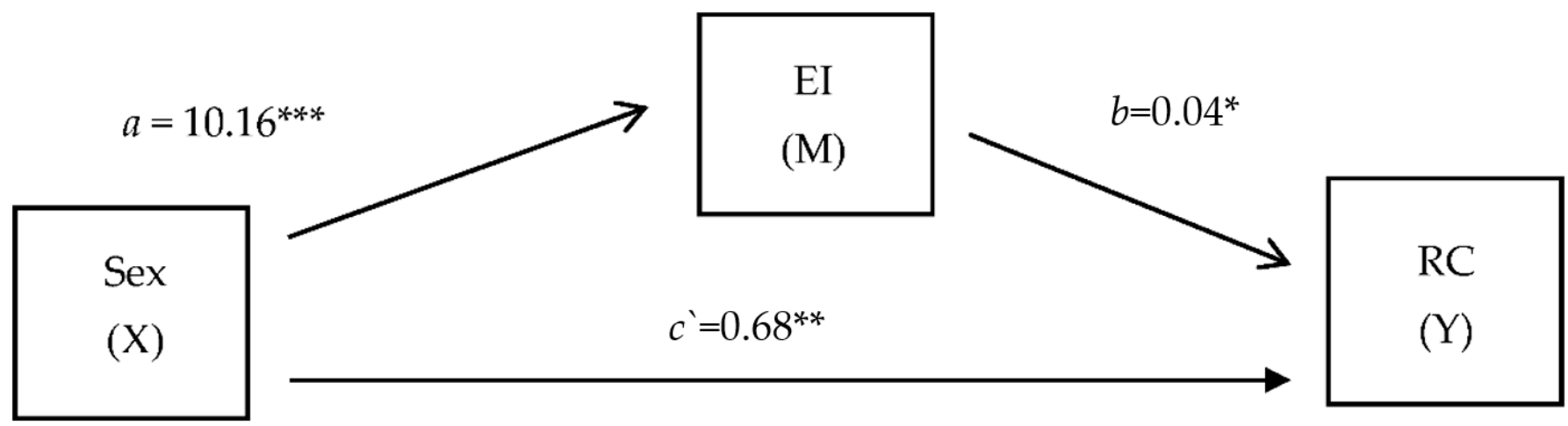

Figure 1. Mediation model showing that the effect of sex on reading comprehension is mediated by emotional intelligence. Note. ${ }^{*} p<0.05 ;{ }^{* *} p<0.01 ;{ }^{* * *} p<0.001$. $\mathrm{X}=$ Independent variable, $\mathrm{M}=$ Mediator variable, $\mathrm{Y}=$ Dependent variable.

The indirect effect was statistically significant $(a \times b=0.39, p<0.001)$, since the 0 was not in the $95 \%$ bootstrap confidence interval $(0.19-0.65)$. This result indicates that of the total effect between the variable sex and $R C(c=1.08, p<0.001)$, part is due to the effect produced by the mediating variable EI, that is, the results show that the presence of the variables EI reduces in 0.39 units the score of the CR in its relationship with the sex. In turn, the indirect effect represents $36.11 \%$ of the total effect, that is, more than a third of the relationship between the variable sex and CR due to the presence of the IE. This highlights a partial mediating effect of EI on the relationship between sex and CR.

\subsection{Moderation Analyses}

A moderation analysis was carried out to evaluate whether the relationship between sex and RC depends on the MRH (objective 2). The results show that the interaction effect is not significant $(\beta=0.75, p=0.17)$, indicating that the relationship between sex and RC does not change at the different levels of the MRH. In other words, regardless of the mother's reading habits, girls show greater reading comprehension than boys (Figure 2).

\subsection{Mediated Moderation Analyses}

This analysis aims to verify whether the relationship between sex and RC is mediated by EI and, in turn, whether this relationship changes depending on the values of the MRH (objective 3). The results show that all effects are statistically significant (Figure 3). 


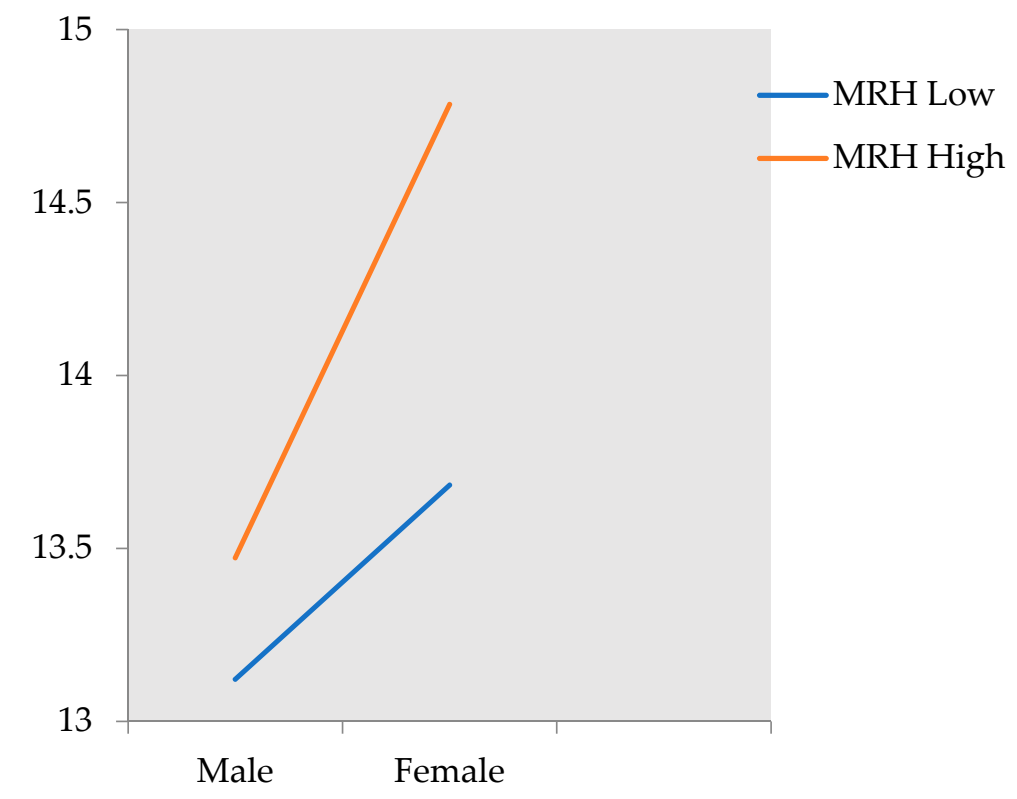

Figure 2. Graph of the reading comprehension score (RC) according to the sex and the mother's reading habit $(\mathrm{MRH})$.

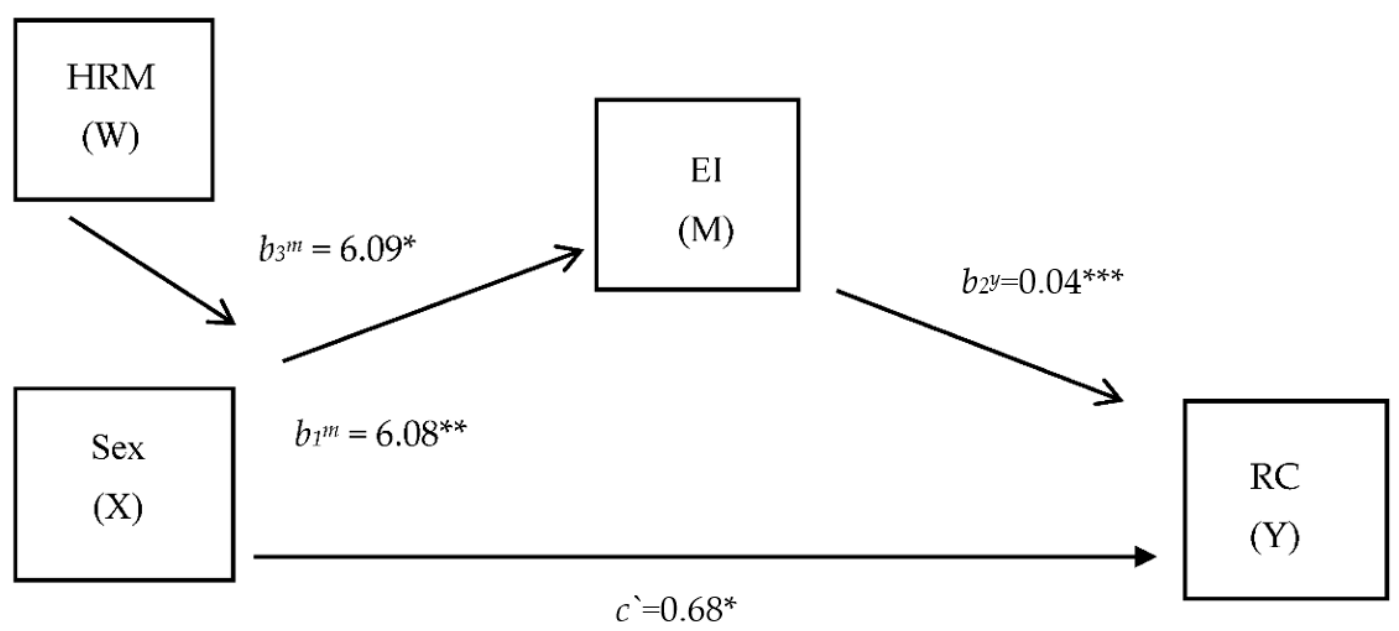

Figure 3. Moderate mediation model. Note. ${ }^{*} p<0.05 ;{ }^{* *} p<0.01 ; * * *<0.001 . \mathrm{X}=$ Independent variable, $\mathrm{M}=\mathrm{Mediator}$ variable, $\mathrm{W}=$ Moderator variable, $\mathrm{Y}=$ Dependent variable.

A significant relationship is again obtained between the variable sex and the IE, the sex and the CR, and the sex and the RC mediated by the EI. These results are consistent with those obtained in the previous analyzes. Finally, the moderate mediation index was statistically significant $(\mathrm{b} 3 \mathrm{~m} \times \mathrm{b} 2 \mathrm{y}=0.24)$, since the 0 was not in the $95 \%$ bootstrap confidence interval (0.02-0.50). This reflects that the effect of the variable sex on the CR is mediated by the IE, and this relationship changes depending on the values that the variable MRH takes, that is, this mediated relationship does not always have the same effect but varies in function of the values that the variable MRH takes. In particular, the results indicate that girls with greater emotional intelligence and whose mothers have higher reading habits score greater reading comprehension.

\subsection{Comparative Analyses}

To examine differences in RC scores according to the sex and the RHM, while controlling the effect of EI, a $2 \times 2$ ANCOVA (objective 4 ) was performed. The factors were sex 
(woman or man) and the mother's reading habits (yes or do not), and the covariable was emotional intelligence.

The results show that the covariable of EI is statistically significant $(F(1,516)=21.57$, $\left.\omega^{2}=0.52, p<0.001\right)$, which indicates that it maintains a linear relationship with RC. This fact justifies the incorporation of the covariable of EI in the analysis because it highlights the effect of EI on the relationship between the factors of sex and MRH and the scores in RC.

The main effect of the sex factor is statistically significant $(\mathrm{F}(1,516)=4.84, p<0.05)$, indicating that adolescent girls show a better adjusted mean in RC scores than boys. Likewise, the magnitude of the association between sex and the RC score obtained by the $\omega^{2}$ partial index was 0.33 , which shows that $33 \%$ of the variance of the RC score is due to the variable of sex, excluding the effect of the variable of MRH. In turn, the effect size calculated from the estimation index $\mathrm{f}$ obtained a value of 1.04 , which shows a very large effect size.

The main effect of the factor of MRH is also statistically significant $(\mathrm{F}(1,516)=4.03$, $p<0.05)$, showing that the adolescents with the highest adjusted means in the RC score are those whose mothers state that they possess the greatest reading habit. The magnitude of the association is high $\left(\omega^{2}\right.$ partial $\left.=0.30\right)$, indicating that $30 \%$ of the variance of reading comprehension scores is due to the mother's reading habits, excluding the effect of sex. The size of the effect obtained is large $(\mathrm{f}=1.04)$. The means and deviations of the main effects of the variables of sex and reading habits of the mother are shown in Table 2. Finally, the interaction effect $(\operatorname{sex} \times \mathrm{MRH})$ is not statistically significant $\left(\mathrm{F}(1,516)=0.98, \omega^{2}\right.$ partial $=0.00$, $p=0.32)$.

Table 2. Descriptive statistics adjusted mean $($ adjusted $M)$ and standard deviation $(S D)$ of the reading comprehension variable $(C L)$ according to sex and the mother's reading habits (MRH).

\begin{tabular}{cccc}
\hline & & \multicolumn{2}{c}{$C \boldsymbol{L}$} \\
\cline { 3 - 4 } & & adjusted $\boldsymbol{M}$ & SD \\
\hline \multirow{2}{*}{ Sex } & Woman & 14.10 & 0.19 \\
& Man & 13.49 & 0.20 \\
MRH & Yes & 14.07 & 0.17 \\
& Do not & 13.53 & 0.21 \\
\hline
\end{tabular}

These results are consistent with those obtained in previous analyses, as they confirm that girls have greater reading comprehension than boys, regardless of the reading habit of the mother.

\section{Discussion}

As we have seen, the scientific literature already points to the importance of the family in the formal education process [1,7-10], not only in childhood but in any of the educational periods through which the human being goes through. In this sense, it is not current feminine empowerment that defines the fundamental role as an educating element of their children, but the traditional way in which society develops currently. In it, women play an irreplaceable role as a family engine, the central axis of the education of children and the primary influence on them, despite the fact that the concept of family unity has evolved considerably and no longer focuses on the triangulation of father, mother and son or children.

Similarly, since Salovey and Mayer [54] determined what is emotional intelligence in the decade of the 90s, for the past ten years a series of studies have been developed with a decisive interest in relation to the world of education. It was inevitable that studies would emerge where parallels and relationships between educational processes and emotions were established. In addition, the importance of reading competence and emotional intelligence for the education of trained and committed citizens, as well as for citizen 
participation, should be specifically highlighted. In this sense, Delgado-Algarra [67] already linked emotional competence with education and citizenship.

And we add that the natural way to train reading competence is reading [2,19], that is, it is not necessary to carry out specific activities or use categorized texts or a battery of specific questions about children's understanding of reading. For instance, Finland, one of the countries that best scores systematically in reading competition, does not contemplate the training of reading competence in its educational system, neither from an official nor extra-school or familiar point of view. However, there is a social relationship with reading that influences the reading competence of its students. Simply, reading is part of their cultural DNA: whole families frequent the library twice a month and, in some cases, carry suitcases to carry books. It is a symbiotic relationship between the culture of reading and reading competence [68].

Therefore, this research has gone beyond the formal studies of motherhood and her emotional intelligence and has focused on maternal reading habits to understand what type of relationship can be established not only with that of the children but with their reading competence, that is, the extent which a social education can influence a formal one: the sustainability of society is rooted in that family education. Thus, in the present study we wanted to establish the fundamental relationship between mothers and their children in the most intuitive sense, not starting from the formal motherhood studies but from their reading habits, and what role emotional intelligence plays as a mediator in this relationship, taking sex differences into account. Then, this is the first study that demonstrates what intuition already pointed out, that is, that reading mothers positively influence both the formal education of their children and their emotional intelligence.

Responding to the initial objectives, the first of them in this investigation is the result of the reading comprehension, sex and emotional intelligence in sons and daughters. In this line, the result of the analysis shows that there is a partial mediation effect of emotional intelligence on the relationship between sex and reading comprehension. However, there are no other conclusive studies that have significant scores between EI and reading comprehension in relation to sex. It is possible to mention the study by Guerra and Guevara [69], which find out statistically significant differences in favor of the male sex in relation to their reading strategies and their motivation towards reading. On the other hand, when including the gender variable in relation to EI and reading comprehension, Castellano [70] does not obtain significant results in this direction.

However, the relationship between sex and reading competence through the mediation of the reading habits of the mother are not significant-that is, girls, regardless of maternal reading habits, score better, which informs us of the second objective raised. On the other hand, maternal reading habits show a significant effect according to gender in reading competence through emotional intelligence, controlling for emotional intelligence, indicating that girls score significantly better than boys in reading competence, within the third objective.

Finally, the emotional intelligence shows a linear relationship with the reading competence, which indicates its influence with respect to this variable. The results show that girls have a better average than boys in reading competition, controlling for the variable of emotional intelligence. Likewise, the reading habits of mothers show a directly proportional influence on the reading competence of their sons and daughters- that is, the greater the reading habit of older mothers, the greater the reading competence of children. In this sense, another study has already shown that the socio-familial context (considering father and mother together) provides a prediction around 20\% in Spanish-speaking countries and $15 \%$ in English-speaking countries; in this case, the most significant incidence on student reading performance is produced by the average educational level of the parents and the parents' involvement in school events or activities, and the educational support to their children [71].

In summary, this study shows the influence exerted by mothers through their reading habits on the development of their children's reading competence. Girls prove to be better 
than boys in competition, independently of this maternal influence, which is why the natural female inclination towards the world of reading stands out, as has already been demonstrated [27,46]. However, the fundamental role of the mother in the family is clear, given the positive influence she exerts on the emotional aspect as well as on the reader, which is in addition to the need for working mothers to reconcile work and family life consistently, in a society with patriarchal biases, as it is our society.

Finally, it should not be forgotten that in order to achieve the Sustainable Development Goals (SDGs) the economic, social, environmental and scientific dimensions are essential, but, in addition, the emotional aspects frame decision-making and actions. Currently, affective, and emotional dimensions are beginning to be influenced, which are very significant in education for sustainability [72].

\section{Conclusions: Limitations and Implications}

We are aware of the limitations of this study. First, the non-random assignment of the study may have led to biases to be considered between the control group and the intervention group. Perhaps it would be necessary to expand the sample randomly to the whole compulsory educational field for a better understanding on how the constructs evolve through the different educational stages, which could help to understand the strengths and weaknesses of the educational systems.

Secondly, this research was carried out during the last week of the course, so it was not possible to control whether the level of stress generated in the period close to the exams worked as a factor that influenced the results of the tests that were collected. In the same line, the level of intellectual fatigue of the sample is beyond our control, since it is unknown if the students were in optimal psychological condition due to the proximity of exams. However, the last week there were no exams and was intended for rest and reflection for the students to be relaxed.

Third, the tests used with the sample - the reading habits test from the Spanish Ministry [65], the emotional intelligence test of Wong and Law (WLEIS) [63], and the ComLEC reading competence questionnaire [62] — are standardized tests in a timed environment that require the intervention of the teacher, who conducted this task independently without our supervision, although they followed our specific instructions on how to collect data through questionnaires.

Fourth, there was no exhaustive control of digital devices such as smart watches or hearing aids to prevent the students from falsifying the data involuntarily in the reading competence questionnaire.

Finally, it is possible that the partial participation in the experiment could have influenced the behavior of the teaching staff, so that the delivery of materials, interviews, and meetings with the professors by the research group and other questions of an investigation of this type could have influenced the results in ways we do not recognize. We stop to decompose the reading competence in cognitive factors that can be trained in a specific way and that require training and effort in the students. The saccadic movement of the eyes, the immediate memory or the strategies of reading comprehension are subjects of investigation of the specialists. Maybe it is time to consider strengthening reading for pleasure in the classroom more firmly, as well as reorganizing school planning by stages and levels. Without forgetting the importance of maintaining contact with families, especially with mothers, and promoting intergenerational reading clubs, or incorporating beneficial customs such as spending Christmas Eve reading after opening gifts, which are always books.

Women's empowerment in today's society should point out the strengths of women within their reading environment, in this case, the home and the family, given the positive influence of the mother on her children. Mothers with greater reading habits have sons and daughters who score significantly better in reading competence, independently of the fact that girls already show higher performance in the constructs of emotional intelligence and reading competence. 
Perhaps governments should design reading as a tool for social improvement, not just for schools, so the publishing industry could be identified as a contributor to the socio-economic development of a country, beyond other industries such as the automobile and technology industries, or even some operations intelligence platforms [73].

Finally, it would be interesting in future research to explore the possible relationship between the editorial investment of countries, with emphasis on the educational field [74], and the economic situation of the countries, including their per capita income and gross domestic product.

Author Contributions: Conceptualization, E.J.-P. and M.-I.d.V.-Y.J.; methodology, E.J.-P., M.-I.d.V.-Y.J. and R.G.-F.; software, P.G.-G.; validation, R.G.-F. and P.G.-G.; formal analysis, M.-I.d.V.-Y.J., R.G.-F. and P.G.-G.; writing-original draft preparation, E.J.-P., M.-I.d.V.-Y.J. and P.G.-G.; writing-review and editing, E.J.-P., M.-I.d.V.-Y.J. and R.G.-F. All authors have read and agreed to the published version of the manuscript.

Funding: This research received no external funding.

Institutional Review Board Statement: Not applicable.

Informed Consent Statement: Not applicable.

Data Availability Statement: Not applicable.

Acknowledgments: The research reported in this document was supported by the Spanish Association of Reading Comprehension of the Kingdom of Spain. The non-profit entity in the statutes recognizes the objectives of research in the field of reading and related areas. We thank our colleagues for their help and recognition. The ethical guidelines used here were previously reviewed and approved by the Ethics Committee of the Spanish Association of Reading Comprehension, AECL.

Conflicts of Interest: The authors declare no conflict of interest.

\section{References}

1. UNESCO. Involucrar a las familias en la alfabetización y el aprendizaje. Notas Polít. UIL 2017, 9, 1-5. Available online: http:/ / unesdoc.unesco.org/images/0024/002494/249463s.pdf (accessed on 4 April 2020).

2. Organisation for Economic Co-operation and Development (OECD). PISA 2018 Reading Literacy Framework. Available online: http:/ / www.educacionyfp.gob.es/inee/dam/jcr:49ede102-244b-4acb-b28e-a7978d9883ed/ReadingFramework.pdf (accessed on 5 July 2020).

3. Ministerio de Educación, Cultura y Deporte. Real Decreto 1105/2014, de 26 de diciembre, por el que se establece el currículo básico de la Educación Secundaria y Obligatoria y del Bachillerato. BOE 2015, 3, 169-546.

4. Collins, J.; Lee, J.; Fox, J.; Madigan, T. Bringing Together Reading and Writing: An Experimental Study of Writing Intensive Reading Comprehension in Low-Performing Urban Elementary Schools. Read. Res. Q. 2017, 52, 1-22. [CrossRef]

5. López-Peñalver, A.; Rodríguez, Y. Plan de Mejora: Animación a la Lectura en Familia. Bachelor's Degree Final Project, Universidad de La Laguna, Tenerife, Spain, 2015.

6. Molina, D.; Berdeal, I.; Mora, E. La preparación de la familia para la atención a la promoción lectora de alumnos de segundo grado. Rev. Conrado 2018, 14, 116-124.

7. González, K.; Arango, L.; Blasco, N.; Quintana, K. Comprensión lectora, variables cognitivas y prácticas de lectura en escolares cubanos. Rev. Wimblu 2016, 11, 39-57. [CrossRef]

8. Grajales, G. Impacto de las TICs en los hábitos lectores de estudiantes de nivel superior. Congr. Mesoam. Educ. 2015, 2, 246-250.

9. Juárez Calvillo, M. Influencia de la formación inicial del profesorado en los hábitos lectores y en el concepto de educación literaria. Investig. Sobre Lect. 2019, 12, 99-115. [CrossRef]

10. Schiefele, U.; Schaffner, E.; Moller, J.; Wigfield, A. Dimensions of Reading motivation and their relation to Reading behavior and competence. Read. Res. Q. 2012, 47, 427-463. [CrossRef]

11. Lara, S.M. El Valor de la Lectura en el Hogar. Bachelor's Degree Final Project, Universidad de Granada, Granada, Spain, 2016.

12. Zuriñe-Mengual, E. Metacomprensión e Inteligencia Emocional. Relación e Influencia en la Comprensión Lectora en el Alumnado de $5^{\circ}$ y $6^{\circ}$ de Educación Primaria. Ph.D. Thesis, Universidad Complutense de Madrid, Madrid, Spain, 2016.

13. Córdoba, E.M.; Quijano, M.C.; Cadavid, N. Hábitos de lectura en padres y madres de niños con y sin retraso lector de la ciudad de Cali, Colombia. Rev. CES Psicol. 2013, 6, 53-65.

14. Gómez-Quina, W.R. Relación entre la Inteligencia Emocional y la Comprensión Lectora en Estudiantes del Primer Año de Educación Secundaria de la Institución Educativa San Martín de Socabaya. M.Sc. Thesis, Universidad Nacional de Arequipa, Arequipa, Peru, 2015. 
15. Parra, M.E. Análisis de las tareas para casa en educación primaria en contextos de diversidad cultural y alto índice de fracaso escolar. Ph.D. Thesis, Universidad de Granada, Granada, Spain, 2017.

16. Pascual, M.R. Influencias de las Metodologías, la Edad Temprana y la Participación de la Familia en el Aprendizaje Lector de los Niños y Niñas Malagueños. Ph.D. Thesis, Universidad de Málaga, Málaga, Spain, 2015.

17. Mirmán, A.; Moreno-Morilla, C. Un evento alfabetizador: La lectura antes de dormir. Edunov. Libros Actas 2016, 466-468. Available online: https: / / dialnet.unirioja.es/servlet/articulo?codigo=5794067 (accessed on 6 February 2021).

18. Márquez, A. Sobre lectura, hábito lector y sistema educativo. Perf. Educ. 2017, 39, 3-17. [CrossRef]

19. Jiménez-Pérez, E. Lectura y educación en España: Análisis longitudinal de las leyes educativas generales. Investig. Lect. 2017, 8 , 79-90. [CrossRef]

20. Braslavsky, B. Enseñar a Entender lo que se Lee: La Alfabetización en la Familia y la Escuela; Fondo de Cultura Económica: Buenos Aires, Argentina, 2005.

21. Cueto, S.; León, I.; Muñoz, I.G.; Rosales, E. Conductas, estrategias, rendimiento en lectura en PISA: Análisis para el Perú. Rev. Iberoam. Calid. Efic. Cambio Educ. 2016, 14, 5-31. [CrossRef]

22. Cervini, R.; Dori, N.; Quiroz, S. Estructura familiar, tamaño de la familia y el rendimiento en matemática y lectura. Perf. Educ. 2016, 38, 12-31.

23. Bahamón, M.M.; Reyes, R.L. Caracterización de la capacidad intelectual, factores sociodemográficos y académicos de estudiantes con alto y bajo desempeño en los exámenes Saber Pro-Año 2012. Av. Psicol. Latinoam. 2014, 32, 459-476. [CrossRef]

24. Garzón, R.; Rojas, M.; Del Riesgo, L.; Pinzón, M.; Salamanca, A. Factores que pueden influir en el rendimiento académico de estudiantes de Bioquímica que ingresan en el programa de Medicina de la Universidad del Rosario-Colombia. Educ. Méd. 2010, 13, 85-96. [CrossRef]

25. Martínez, V. Investigación y reflexión sobre los condicionantes del fracaso escolar. Rev. Latinoam. Estud. Educ. 2009, 39 , 11-38.

26. Meseguer, J. En qué se parecen los países con mejor rendimiento escolar. Rev. Antig. Alumnos IEEM 2011, 14, 85-89.

27. Jiménez-Pérez, E. Comprensión lectora vs. Competencia lectora: Qué son y qué relación existe entre ellas. Investig. Lect. 2014, 1, 65-74. [CrossRef]

28. Santana, R.; Alemán, J.A.; López, M. Leer por placer: ¡lo primero, oír los libros! Aula Abierta 2017, 46, 83-90. [CrossRef]

29. Miller, D.; Topping, K.; Thurston, A. Peer tutoring in reading: The effects of role and organization on two dimensions of self-esteem. Br. J. Educ. Psychol. 2010, 80, 417-433. [CrossRef]

30. Mora-Figueroa, J.; Galán, A.; López-Jurado, M. Efectos de la implicación familiar en estudiantes con riesgo de dificultad lectora. Ocnos 2016, 15, 7-21. [CrossRef]

31. Moreno, E. Análisis de la influencia de la familia en los hábitos lectores de sus hijas e hijos: Un estudio etnográfico. Context. Educ. 2001, 4, 177-196. [CrossRef]

32. Córdoba, E.M.; Cadavid, N.; Quijano, M.C. Hábitos y expectativas lectoras de padres niños con dificultad lectora. Rev. CES Psicol. 2015, 8, 31-46.

33. Guzmán-Simón, F.; García-Jiménez, E. Los hábitos lectoescritores en los alumnos universitarios. Rev. Electr. Interuniv. Form. Profr. 2014, 17, 79-92. [CrossRef]

34. Salvador-Oliván, J.A.; Agustín-Lacruz, M.C. Hábitos de lectura y consumo de información en estudiantes de la Facultad de Filosofía y Letras de la Universidad de Zaragoza. Anal. Doc. 2015, 18, 2-15. [CrossRef]

35. Jiménez-Pérez, E. Una visión didáctica sobre la realidad de Miguel Hernández en Internet. Islas 2010, 165, 25-32.

36. Sánchez, C. Comprensión lectora en español como segunda lengua para fines específicos. In Educación Lectora; Jiménez-Pérez, E., Ed.; Síntesis: Madrid, Spain, 2017; pp. 141-147.

37. de Vicente-Yagüe Jara, M.I. Un nuevo enfoque de la lectura musical. Análisis literario, musical y didáctico del cuento Mi madre la Oca. Investig. Lect. 2014, 2, 15-23.

38. Labín, A.; Taborda, A.; Brenlla, M. La relación entre el nivel educativo de la madre y el rendimiento cognitivo infanto-juvenil a partir del WISC-IV. Psicogente 2015, 18, 293-302. [CrossRef]

39. Martínez, J.S.; Córdoba, C. Rendimiento en lectura y sexo: Una pequeña diferencia motivada por factores sociales. In PIRLSTIMSS 2011. Estudio Internacional de Progreso en Comprensión Lectora, Matemáticas y Ciencias. Volumen II: Informe Español. Análisis Secundario; Ministerio de Educación, Cultura y Deporte; Instituto Nacional de Evaluación Educativa: Madrid, Spain, 2012; pp. 143-179.

40. de Vicente-Yagüe Jara, M.I.; González Romero, M. Percepción de los maestros y las familias del alumnado de Educación Infantil acerca de la lectura y la audición musical. In Educación Lectora; Jiménez-Pérez, E., Ed.; Síntesis: Madrid, Spain, 2016; pp. 197-204.

41. de Vicente-Yagüe Jara, M.I.; González Romero, M. Análisis de un planteamiento metodológico interdisciplinar en Educación Infantil para el fomento de la lectura. Rev. Complut. Educ. 2019, 30, 163-178.

42. Vicas, L.M. Acompañamiento escolar de hijos por sus madres que trabajan en el Ministerio de Salud del Distrito de Huancayo. Horiz. Cienc. 2017, 7, 167-191. [CrossRef]

43. Larrañaga, E.; Yubero, S. El valor de la lectura en relación con el comportamiento lector. Un estudio sobre los hábitos lectores y el estilo de vida en niños. Ocnos 2010, 6, 7-20. [CrossRef]

44. Blázquez-Garcés, J.V.; Fernández-Andrés, M.I.; Sanz-Cervera, P.; Tijeras, A.; Vélez, X.; Pastor-Cerezuela, G. Comprensión lectora y oral: Relaciones con CI, sexo y rendimiento académico de estudiantes en educación primaria. Int. J. Dev. Educ. Psychol. INFAD Rev. Psicol. 2015, 1, 307-313. [CrossRef] 
45. Ghabanchi, Z.; Rastegar, R. The correlation of IQ and Emotional Intelligence with the Reading Comprehension. Read. Matrix 2014, $14,135-144$.

46. Jiménez-Pérez, E.; Alarcón, R.; de Vicente-Yagüe, M.I. Intervención lectora: Correlación entre la inteligencia emocional y la competencia lectora en el alumnado en bachillerato. Rev. Psicodidáct. 2019, 24, 24-30.

47. Páez, M.L.; Castaño, M.S. Inteligencia emocional y rendimiento académico en estudiantes universitarios. Psicol. Caribe 2015, 32, 269-285.

48. Alonso, L. Inteligencia Emocional y Rendimiento Académico: Análisis de Variables Mediadoras. Bachelor's Thesis, Universidad de Salamanca, Salamanca, Spain, 2014.

49. Vilches, I. Inteligencia emocional en la asignatura de Lenguaje y Comunicación. Contexto Estud. Humanid. Cienc. Soc. 2004, 12, 77-86.

50. Durlak, J.A.; Dymnicki, A.B.; Taylor, R.D.; Weissberg, R.P.; Schellinger, K.B. The impact of enhancing students' social and emotional learning: A meta-analysis of school-based universal interventions. Child Dev. 2011, 82, 405-432. [CrossRef]

51. Delgado, M.L. Influencia de la comprensión verbal y la memoria de trabajo en la asignatura de lengua castellana en Educación Infantil. Master's Thesis, UNIR, La Rioja, Spain, 2016.

52. Sullivan, A.; Brown, M. Social Inequalities in Cognitive Scores at Age 16: The Role of Reading; Centre for Longitudinal Studies: London, UK, 2013.

53. Guzmán, B.; Véliz, M.; Reyes, M. Memoria operativa, comprensión lectora y rendimiento académico. Lit. Lingüíst. 2017, 35, 379-404. [CrossRef]

54. Mayer, J.; Salovey, P. What Is Emotional Intelligence? In Emotional Development and Emotional Intelligence: Educational Implications; Salovey, P., Sluyter, D.J., Eds.; Basic Books: New York, NY, USA, 1997; pp. 3-31.

55. Caballero, A.; García-Lago, V. La lectura como factor determinante del desarrollo de la competencia emocional: Un estudio hecho con población universitaria. Rev. Investig. Educ. 2010, 28, 345-359.

56. Hogan, P.C. What Literature Teaches Us about Emotion; Cambridge University Press: New York, NY, USA, 2011.

57. Menéndez, M. El desarrollo de la creatividad y de la inteligencia emocional del niño a través de la lectura. 1997. Available online: http:/ / www.waece.org/biblioteca/pdfs/d082.pdf (accessed on 16 April 2020).

58. Johnson, D.R. Transportation into a story increases empathy, prosocial behavior, and perceptual bias toward fearful expressions. Personal. Individ. Differ. 2012, 52, 150-155. [CrossRef]

59. Aram, D.; Aviram, S. Mothers' Storybook Reading and Kindergartners' Socioemotional and Literacy Development. Read. Psychol. 2009, 30, 175-194. [CrossRef]

60. Adrián, J.E.; Clemente, R.A.; Villanueva, L. Mothers' Use of Cognitive State Verbs in Picture-Book Reading and the Development of Children's Understanding of Mind: A Longitudinal Study. Child Dev. 2007, 78, 1052-1067. [CrossRef]

61. Adrián, J.E.; Clemente, R.A.; Villanueva, L.; Rieffe, C. Parent-child picture-book reading, mothers' mental state language and children's theory of mind. J. Child Lang. 2005, 32, 673-686. [CrossRef]

62. Llorens, A.C.; Gil, L.; Vidal-Abarca, E.; Martínez, T.; Mañá, A.; Gilabert, R. Prueba de Competencia Lectora para Educación Secundaria (CompLEC). Psicothema 2011, 23, 808-817.

63. Fernández-Berrocal, P.; Pérez, J.C.; Repetto, E.; Extremera, N. Una comparación empírica entre cinco medidas breves de inteligencia emocional percibida. In Proceedings of the VII European Conference on Psychological Assessment, Malaga, Spain, 1-4 April 2004.

64. Wong, C.S.; Law, K.S. The effects of leader and follower emotional intelligence on performance and attitude: An exploratory study. Leadersh. Q. 2002, 13, 243-274. [CrossRef]

65. Ministerio de Educación, Cultura y Deporte. Encuesta sobre Hábitos Lectores de la Población Escolar entre 15 y 16 Años; Dirección General De Educación, Formación Profesional e Innovación Educativa: Madrid, Spain, 2001.

66. Al Nima, A.; Rosenberg, P.; Archer, T.; García, D. Anxiety, Affect, Self-Esteem, and Stress: Mediation and Moderation Effects on Depression. PLoS ONE 2013, 8, e73265. [CrossRef]

67. Delgado-Algarra, E. Educación y ciudadanía y competencia emocional en la enseñanza de las ciencias sociales. El manga como recurso educativo. In Nuevas Visiones sobre el Cómic: Un Enfoque Interdisciplinar; Gracia, J.A., Asión, A., Eds.; Prensas Universitarias de Zaragoza: Zaragoza, Spain, 2018; pp. 287-292.

68. Vahapassi, A. Reading Comprehension in Primary Education in Finland. In Reading and Writing Skills in Primary Education; Young, M., Thomas, M., Munn, P., Eds.; CRC Press: London, UK, 2020; pp. 1-7.

69. Guerra, J.; Guevara, C.Y. Variables académicas, comprensión lectora, estrategias y motivación en estudiantes universitarios. Rev. Electr. Investig. Educ. 2017, 19, 78-90. [CrossRef]

70. Castellano, J.E. Inteligencia Emocional y Comprensión Lectora en Alumnos de Sexto Grado de Primaria de la Red n. ${ }^{\circ} 4$ Distrito del Callao. Bachelor's Degree Final Project, Universidad San Ignacio de Loyola, La Molina, Peru, 2010.

71. Vázquez-Cano, E.; De-la-Calle-Cabrera, A.-M.; Hervás-Gómez, C.; López-Meneses, E. El contexto sociofamiliar y su incidencia en el rendimiento lector del estudiante en PISA. Ocnos 2020, 19, 43-54. [CrossRef]

72. Martínez-Agut, M.P. Educación y competencia socioemocional en la educación para la sostenibilidad: La sostenibilidad socioemocional. In Proceedings of the XXXVII Seminario Interuniversitario de Teoría de la Educación: Educación en la Sociedad de Conocimiento y el Desarrollo Sostenible, Universidad de La Laguna, Tenerife, Spain, 11-14 November 2018. 
73. Fedushko, S.; Ustyianovych, T. Operational Intelligence Software Concepts for Continuous Healthcare Monitoring and Consolidated Data Storage Ecosystem. In Advances in Computer Science for Engineering and Education III; Hu, Z., Petoukhov, S., Dychka, I., He, M., Eds.; Springer: Cham, Switzerland, 2020; Volume 1247, pp. 545-557.

74. Zaldívar Sansuán, R. The emotional dimension in poetic education as a key to improve adolescents' attitudes towards poetry. Investigaciones Sobre Lectura 2020, 14, 75-93. [CrossRef] 